\title{
Para Marielle Franco, na luta por um país mais democrático e justo!
}

Floriano José Godinho de Oliveira, Leandro Dias de Oliveira, Guilherme Ribeiro e Désirée Guichard Freire

\section{Q OpenEdition \\ 12 Journals}

Edição electrónica

URL: http://journals.openedition.org/espacoeconomia/3120

DOI: $10.4000 /$ espacoeconomia.3120

ISSN: 2317-7837

Editora

Núcleo de Pesquisa Espaço \& Economia

Refêrencia eletrónica

Floriano José Godinho de Oliveira, Leandro Dias de Oliveira, Guilherme Ribeiro e Désirée Guichard Freire, «Para Marielle Franco, na luta por um país mais democrático e justo! », Espaço e Economia [Online], 11 | 2017, posto online no dia 07 abril 2018, consultado o 24 setembro 2020. URL http://journals.openedition.org/espacoeconomia/3120 ; DOI : https://doi.org/10.4000/ espacoeconomia.3120

Este documento foi criado de forma automática no dia 24 setembro 2020.

(C) NUPEE 


\title{
Para Marielle Franco, na luta por um país mais democrático e justo!
}

\author{
Floriano José Godinho de Oliveira, Leandro Dias de Oliveira, Guilherme \\ Ribeiro e Désirée Guichard Freire
}

1 Cidade do Rio de Janeiro, sob Intervenção Militar, noite de 14 de março de 2018.

2 Marielle Franco, 38 anos de idade, nascida na Favela da Maré, socióloga com mestrado em Administração Pública, vereadora carioca eleita com 46.502 votos vinculada ao Partido Socialismo e Liberdade (PSOL), retornava de um debate com jovens negras na Casa das Pretas, situada na Lapa, por volta das 21 horas. Em seu carro, estavam uma assessora e o motorista Anderson Pedro Gomes, 39 anos, pai do pequeno Arthur, de 2 anos. Quando atravessavam a Rua Joaquim Palhares, no bairro do Estácio, 13 tiros foram disparados de um carro emparelhado ao da vereadora e destruíram sua vida e a de seu motorista, numa execução covarde, bárbara e inaceitável em uma democracia. Os disparos que alvejaram Marielle --- mulher, negra, mãe, combativa --- estilhaçaram sonhos e macularam todos aqueles que lutam por dias melhores.

3 É dolorosa a certeza de que Marielle tenha sofrido este atentado por suas posições políticas! Crítica da intervenção militar, da violência contra os desvalidos e da ordem hegemônica de raça, credo, gênero e orientação sexual, a violência descomunal contra a vereadora reverbera o advento de tempos de intolerância, de beligerância e de barbárie. A grande quantidade de manifestações e homenagens emocionantes nas ruas e redes sociais à memória da vereadora não esconde a perplexidade de enfrentar um significativo número de pessoas que relativizaram sua morte, se regozijaram pela supressão de suas ideias e buscaram, mais uma vez, culpar a vítima.

4 Diante deste nefasto quadro, reforçamos: nossa luta não esmorecerá. Os choros, os gritos e as mensagens que ecoaram por todo o Brasil evidenciaram o fato de que, mesmo estupefatos com a ignorância política vigente e beligerância daqueles que se apossaram do poder em nosso país, estamos todos fortalecidos para enfrentar os tempos difíceis que assistimos. Todos nós sabemos que não será simples, mas não esmoreceremos. Reforçamos aqui o nosso papel na construção de um país mais democrático e justo. 
6 Sentidamente, dedicamos este número de Espaço e Economia: Revista Brasileira de Geografia Econômica à memória de Marielle Franco.

7 Marielle presente! Anderson Presente! Hoje e Sempre!

8 NuPEE, UERJ-UFRRJ, Rio de Janeiro, 25 de março de 2018.

\section{AUTORES}

\section{FLORIANO JOSÉ GODINHO DE OLIVEIRA}

Doutor em Geografia pela USP, com pós-doutorado pela Universidade de Barcelona. Professor do Programa de Políticas Públicas e Formação Humana (PPFH) da UERJ. E-mail:

fgodinhodeoliveira@gmail.com.

\section{LEANDRO DIAS DE OLIVEIRA}

Doutor em Geografia pela UNICAMP. Professor do Departamento de Geografia e do Programa de Pós-Graduação em Geografia da UFRRJ - Universidade Federal Rural do Rio de Janeiro. E-mail: ldiasufrrj@gmail.com.

\section{GUILHERME RIBEIRO}

Doutor em Geografia pela UFF, com estágio doutoral pela Universidade de Paris - Sorbonne (Paris IV). Pós-Doutor pela UFMG. Professor do Departamento de Geografia e do Programa de PósGraduação em Geografia da UFRRJ - Universidade Federal Rural do Rio de Janeiro. E-mail: geofilos@msn.com.

\section{DÉSIRÉE GUICHARD FREIRE}

Professora do Departamento de Geografia da UERJ-Faculdade de Formação de Professores. E-mail: desireeuerj@gmail.com. 